\title{
Corruption and Reform in Higher Education in Ukraine
}

\author{
Ararat L. Osipian (Vanderbilt University)
}

\begin{abstract}
At least thirty percent of Ukrainians enter colleges by paying bribes while many others use their connections with the faculty and administration. Corruption increases inequalities in access to higher education, prevents future economic growth in the country, and undermines quality and credentials of academic degrees. This paper considers corruption in higher education in Ukraine, including such aspects as corruption in admissions to higher education institutions and corruption in administering the newly introduced standardized test. The reform of higher education in Ukraine, based on the national examinations, is intended to be a response to the rapidly changing economic environment and the new social order.

Résumé

Au moins un tiers des étudiants ukrainiens des collèges universitaires a été admis en payant des potsde-vins, le reste s'est servi de ses contacts avec les départements académiques et administratifs. La corruption accentue un accès inégal aux universités, freine la croissance économique future du pays et remet en question la qualité et les cartes de présentation des diplômes académiques. Cet article vise la corruption dans les universités ukrainiennes et plus précisément, la corruption lors des processus d'admission dans les institutions d'éducation supérieure ainsi que dans l'administration du nouvel examen standard utilisé à cet effet. La réforme de l'éducation supérieure en Ukraine, basée sur l'application d'examens nationaux, cherche à répondre à un nouvel ordre économique et surtout à un environnement économique en constante mutation.
\end{abstract}

\section{INTRODUCTION}

The process of globalization leads to increasing international trade in higher education. Along with processes of labor migration it makes educational credentials extend from the realm of national educational systems into international relations. Skills and qualifications are notarized in educational certificates. But what if certificates are fake, qualifications are overestimated or institutions exist only on paper? This raises the issue of corruption in higher education.

Ukraine has a strong tradition of educating students from abroad, mostly from the developing nations. The system of selecting and educating students from overseas was developed in Soviet times. Universities are active in the international arena to offer their educational services and generate revenues. According to Kerr, "For the first time, a really international world of learning, highly competitive, is emerging. If you want to get into that orbit, you have to do soon merit." (Kerr, 1993, p. 33) Corruption, rampant in Ukrainian higher education institutions (HEIs), undermines the quality of education and its status in the educational services market.

Internationalization in education touches on the issue of immigration and the international labor market. The immigration flow from Ukraine is mostly 
directed to the Russian Federation, European Union, the US, and Canada (Ministerstvo, 2008). Educational credentials of Ukrainians in other countries are not well received. First, the language is a natural barrier, but more importantly, solid modern knowledge is often lacking. The Bologna Declaration and Lisbon Convention adopted by Ukraine are intended to integrate the nation's education sector into the larger European community. However, if the situation with corruption does not change drastically, international credential recognition will not be possible. This problem is common for the former Soviet republics. Heyneman, Anderson, and Nuraliyeva (2008) point out that "Whether experienced or perceived, universities or university systems with reputations for corruption will likely end the Bologna process. Were this process to actually take effect it would constitute the educational equivalent in the EU of unilateral disarmament.” (p. 1) Countries with a high level of credibility and low level of corruption are unlikely to recognize educational credentials from the countries where degrees are bought and sold. This may lead to the collapse of the initiative of creating a common educational space within the larger Europe.

This paper addresses the issue of corruption in higher education in Ukraine as well as the reform that aims at modernizing the higher education sector and curbing corruption. It uses official reports and documents, reports and comments in mass media, and results of surveys as an informative base for the research.

\section{CORRUPTION IN ACADEMIA: DEFINITIONS AND FORMS}

Corruption in higher education is by no account a new phenomenon. It was commonplace in medieval universities, including in Bologna and the Sorbonne (Osipian, 2004a, 2004b). The word corruption comes from the Latin word corruptio, which in Medieval Latin expressed a moral decay, wicked behavior, putridity, rottenness (Johnston, 1996, p. 322). Milovanovic says that in this context one could talk of bribes, or other dishonest means for achieving particular disgraceful ends, as a symptom of an ailing society (Milovanovic, 2001).

Osborne sees corruption as "a loss of purity and purpose, a social decomposition.” (Osborne, 1997) For Anechiarico and Jacobs, the definition of education corruption includes the abuse of authority for material gain (Anechiarico and Jacobs, 1995). Heyneman adds to this definition by arguing the following: "But because education is an important public good, its professional standards include more than just material goods; hence the definition of education corruption includes the abuse of authority for personal as well as 
material gain.” (Heyneman, 2004, p. 638) Miller, Roberts, and Spence (2005) point to the relativeness of the term corruption as applied to academia.

Ukrainian authors refer to the International Institute for Educational Planning's definition of corruption in education as a "misuse of public office for private gain that influences access, quality, and equity in education." (Bazhal et al., 2006) Sayed and Bruce (1998) and Waite and Allen (2003) present a broad social approach to define corruption. This paper adheres to Petrov and Temple's (2004) approach to corruption and applies a narrow definition of corruption that regards corruption as such only if it implies illegality. It uses the operational definition of corruption in higher education as a system of informal relations established to regulate unsanctioned access to material and nonmaterial assets through abuse of the office of public or corporate trust (Osipian, 2007a, p. 314). Hallak and Poisson (2007) present a wide range of misconduct that may be found in academia throughout the world (Osipian, 2008e). Corruption may be found not only in colleges, but in doctoral education as well (Osipian, 2010, 2009f).

Several forms of corruption may be found in higher education in Ukraine and other former Soviet republics. Forms of corruption include bribery, embezzlement, extortion, fraud, ghost instructors, abuse of public property, nepotism, cronyism, favoritism, kickbacks, cheating, plagiarism, and research misconduct. They rarely appear on their own. Forms of corruption are often connected in bundles. For instance, assigning a high grade to a student in exchange for a bribe implies fraud. A form itself can have different origins. A bribe can be offered voluntarily or extorted. It can be in the form of cash, merchandize, service, or a monetary donation. Silova, and Bray (2006) describe the black market of private tutoring in former Socialist countries. In addition to classical forms of corruption, gross waste in educational management and sexual misconduct take place in higher education institutions in Ukraine as well as many other countries.

\section{HIGHER EDUCATION CORRUPTION INTERNATIONALLY}

Hallak and Poisson (2007) attempt to present academic corruption in its entirety all over the world, while grounding their work in the evidence derived from secondary sources. The authors use a managerial approach to corruption, helpful for administrators of educational institutions. Hallak and Poisson (2007) present the first systematic overview of forms of academic corruption throughout the world, which makes their study unique. In addition, there are numerous media accounts of higher education corruption that describe its prevalence, patterns, and forms in many countries. However, systematic rigorous research on the issue is virtually nonexistent. Shaw (2005) and Heyneman, Anderson, and Nuraliyeva 
(2008) present a quantitative analysis of corruption in higher education in Ukraine, and in Central Asia, respectively. Osipian (2007e, 2008d) presents a systematized content analysis of media reports on corruption in higher education in the US, the UK, and the Russian Federation, placing them in the context of reforms and major changes in the industry. International perspectives on corruption in higher education are also presented in Osipian (2007h).

Theorizing higher education corruption, including state-university relations, concepts of corruption, and methodological approaches to its comparisons and measurements may be found in Osipian (2008a, 2008c, 2007i). Heyneman (2004) offers quite an exhaustive list of functions of higher education institutions and the way in which they become corrupted. Both authors built their theories while focusing primarily on the countries of the former Soviet Bloc.

Theorizing corruption in academia extends into modeling and developing possible hierarchical structures of corruption that exist in universities. Osipian (2008b) offers advanced quantitative techniques for modeling misconduct in large educational organizations. Corruption hierarchies in education in developing and transition societies are modeled and analyzed by Waite and Allen (2003), Petrov and Temple's (2004), and Osipian (2006, 2007c, 2009d, 2009h). The authors study corruption in higher education, including from an organizational perspective, by pointing out differences between bribery and extortion, channeling illicit benefits through the layers of hierarchical structures, and vertical and horizontal axes of informal authority and power that exist in corrupt colleges and universities.

Higher education corruption may be found in many national systems from Central Asia (Osipian, 2009a) to the US (Osipian, 2009c, 2009e). Regionwise, scholarly work on academic corruption is focused disproportionately on the countries of the former Soviet Bloc. This may be explained by at least tree facts. First, the higher education sector in the former socialist countries was large and highly developed. Because of its size and significance, it attracts attention. Second, rapid socio-economic and political changes led to a dramatic increase in corruption, including in higher education. Finally, the former Soviet republics undertake unprecedented education reforms, including introduction of standardized national testing and privatization (Osipian, 2009b). The size of the system and the scale of the problem urge scholars to investigate both forms of illicit activities and causes of such activities. Accordingly, Russia, Ukraine, and Central Asia are attracting much attention of the media and, lately, of scholars as well.

Satarov (2006) offers a survey based analysis of corruption process in Russia, focusing on such issues as the level of corruption, corruption markets, 
structure of the problem, and major trends. He points out to an increase in corruption in the education sector, including higher education, since 2001. Statarov (2006) confirms that higher education is one of the most corrupt sectors of the Russian economy, if not the most corrupt one. The reform of Russian higher education and measures against corruption, including the introduction of standardized testing, are presented in Osipian (2007d, 2007g). One of the reasons why the Russian leadership agreed to replace university entry examinations with standardized tests was with the intent to reduce the level of corruption in academia. Petrov and Temple (2004) study corruption in Russian universities and compare it to corruption that takes place in universities in Azerbaijan. They come to the conclusion that while in Russia bribery from faculty members is rather need-based, i.e. explained by their low salaries, in Azerbaijan it is more of a direct extortion, when college faculty collect informal payments from just about every student.

Tarling (2005) offers some theoretical explanations regarding corruption and good governance in Asian countries. Silova, Johnson, and Heyneman (2007) present a comprehensive overview and analysis of education corruption and the crisis of social cohesion in Azerbaijan and Central Asia. Silova (2005) also offers an analysis of problems, faced by the education sector in Central Asia. The explanatory concept "Feed from the service" is offered in Osipian (2007f). It describes the model of corruption and coercion in the state-university relations based on the mosaics of facts about academic corruption that takes place in the region. Heyneman (2007) presents an interview based research conducted in three universities in Georgia, Kazakhstan, and Kyrgyzstan. The author shows different aspects of the ongoing struggle against corruption and for social cohesion that takes place in these former Soviet republics.

Sanghera and Romanchuk (2002) describe bribery and other forms of corruption in Kyrgyz state universities. They underline the far reaching possible consequences of corruption in education, including ethical implications, erosion of professionalism and academic values, and the negative impact on the national economy. Along with Sanghera and Romanchuk (2002), Reeves (2004) points out that "the result is not only the production of underqualified specialists whose real knowledge corresponds only remotely with the list of courses detailed on their diplomas. Another effect is a much more profound societal skepticism regarding assertions of educational expertise.” A real battle for the restoration of academic integrity and reform in Georgian higher education is reflected in works of Heyneman (2007), Janashia (2004), and Temple (2006).

Former Soviet republics, including Russia and those in the Central Asian region are certainly not alone in the list of notoriously corrupted national 
educational systems. According to some initial studies and comments, Chinese higher education sector suffers of rampant corruption as well. It penetrates different areas of this industry and corrupts its functions. Yang (2005) points out that "Individual violations are closely related to the way the system operates. While economic and political corruption attracts widespread attention, academics avoid scrutiny due to the special nature of their profession but have also abandoned the traditional values of the university." He reports corruption in academic research, administration, promotions, doctoral education, and other spheres, calling China's academe a "plagiarist's paradise.” Rampant corruption undermines academic standards and worth of the degrees and credentials: "Cash, power, and influence become corrupting factors and compromise academic standards.” Illicit dealings between universities, businessmen and government officials add to corruptness of academia. Yang (2005) concludes that corruption greatly hinders the internationalization of China's higher education and is detrimental to scholarly exchanges.

Literature on academic corruption in Ukraine includes quantitative analyses of bribery and other patterns of illicit behavior, conducted by Shaw (2005), a study of corruption and politicization of universities that can be observed during the Orange Revolution (Osipian, 2005), as well as an analysis of higher education corruption in Ukraine as reflected in the national media (Osipian, 2007b, 2007j). This includes opinions and estimates of current situation and future perspectives, presented by the leading Ukrainian educators. Stetar, Panych, and Cheng (2005) confirm that "the role of bribery in Ukrainian higher education has become corrosive, and a small number of education leaders from both the private and state sectors are beginning to challenge the system."

\section{FACTS ABOUT CORRUPTION IN UKRAINE'S HIGHER EDUCATION SECTOR}

Law enforcement agencies attempt to confine corruption within the certain reasonable limits by deterring faculty members from unreasonably risky or highscale corrupt activities. For instance, the Chief of the Center of Public Relations of the Ministry of the Interior in Ternopilska oblast, Sergij Shvornikov, reports that a forty year-old Associate Professor in one of the region's HEIs was detained for demanding bribes from the students. The detained professor allegedly distributed the students a price list prior to the spring examination session: "In order to receive C or 'satisfactory' one would have to pay $50 \mathrm{UAH}, \mathrm{B}$ or 'good' $100 \mathrm{UAH}$, and A or 'excellent' was priced at $150 \mathrm{UAH}$.” (Unian, 2007) The exchange rate is currently around $5 \mathrm{UAH}$ for $\$ 1$. Accordingly, C costs $\$ 10$, B costs $\$ 20$, and A costs $\$ 30$. For comparison, the average monthly wage in 
Ukraine in 2007 was equal to $\$ 250$. The professor was caught red-handed and arrested while accepting a bribe of 650UAH, or $\$ 130$ (Osvita, 2007). The national news agency UNIAN commented on the case in a piece entitled "The season of bribes in HEIs has begun," pointing to the fact that corruption in HEIs experiences resurgence twice a year, when the examination period starts (Unian, 2007).

A departmental chair in Lugansk demanded that students pay his bills from electronics and construction stores and he accepted cash as well. The corrupt chair was arrested while receiving a bribe of $10000 \mathrm{UAH}$ or $\$ 2000$. In yet another case, the deputy-director of the Kiev National University's college was arrested while receiving a bribe of $\$ 5000$ plus 5000UAH. There were 210 cases of bribery registered in higher education institutions in the first six months of 2006, of which 11 were in Kiev (Grishina and Korchinsky, 2006).

The number of cases of bribery in higher education, reported by the Ministry of the Interior, appears to be but the tip of the iceberg for the industry, plagued with corruption. According to the survey conducted by the Millennium Challenge Corporation with the support of the Ukrainian government, corruption riddled all the spheres of the economy and society, not limiting itself to the public sector. The respondents consider higher education institutions as the most corrupted organizations, followed by hospitals and polyclinics, law enforcement agencies, and tax collection offices. Fifty-two percent of the citizens consider corruption as the easiest and most reliable way of solving many problems. Moreover, this view is more characteristic of the younger generation that constitutes the student body and will eventually define the nation's future.

The scale and scope of corruption in Ukraine's education industry is impressive, indeed. It might be no different from many other countries, and is likely less than in most of the other former Soviet republics, but the rate of growth of the criminal activities in education is alarming. At the same time the number of accused is incredibly small, because students, their parents, and colleagues of corrupt faculty members tend not to report cases of corruption. Moreover, an act of corruption is considered as a mutually beneficial agreement. Students often welcome an opportunity to improve their grades by paying bribes while parents offer bribes to secure admission of their children to a HEI. Bribery is very difficult to prove when both sides are satisfied with the results of a corrupt transaction. While complaining about the high level of corruption in general, students are rarely willing to turn in corrupt professors, even in cases of direct extortion.

Students contribute to corruption by choosing an easy but illegal way of receiving good grades. Many students either create situations for corruption or 
would not miss a chance of improving their grades in exchange for bribes, if such an offer came from their professor. The survey shows that the share of such students equals 21 percent in Donetskaya oblast, 29 percent in Kiev, 28 percent in Lviv, 25 percent in Odessa, and 30 percent in Kharkov. Another 15 percent of the respondents said that they would not take advantage of such offer but would inform their friends of the existing opportunity. Only 21 to 26 percent of all students, depending on the region, would refuse to do this. Finally, only 3 to 8 percent would inform the police. At the same time 42 percent of the parents of the prospective students said that instead of wasting time on preparation of their children for college entry examinations they would rather seek other ways and means, including informal payments and connections (Bazhal et al., 2007). Gifts are considered a norm in HEIs (Km.ru, 2007).

Private tutoring is thought to be a form of corruption in admissions as well. A payment of $\$ 2000$ to $\$ 4000$ to a private tutor who is also a professor at a leading university may help in gaining admission to the program where he teaches (Grishina and Korchinskij, 2006). A conflict of interest arises when an applicant takes his oral entry examination with the professor who tutored him before, specifically for this examination. However, private tutoring is legal. Many college professors offer formally registered consulting services and pay taxes from their income. Therefore, it is impossible to say whether the payment for tutoring services, even if unreasonably high, is actually a bribe. Private tutors who are also members of the admission committee are especially popular among the applicants.

Corruption in higher education is not limited to academic corruption. Embezzlement, fraud, gross waste, misallocation of resources, and other corrupt activities are found throughout the country. One of the latest investigations reports that the former president of the Lugansk branch of the Inter-Regional Academy of Personnel Management [Mizhregionalna Akademiya Upravlinnya Personalom (MAUP)] embezzled 831.9 thousand UAH (CityNews, 2006). The relations between MAUP, one of the largest private for-profit providers of educational services in the country, and the Ministry of Education and Science are quite tense, with challenges and mutual accusations being voiced in the media. The website of this educational institution offers, among other services, a US-format Ph.D. in Psychology through another higher education institution, based in Honolulu, Hawaii. The Hawaii-based "university" is a notorious diploma mill, evicted from the state by the court decision.

Diploma mills and low quality educational programs, previously unknown in Ukraine, can now be found in form of branches of public and private higher education institutions. The State Attestation Commission [Derzhavna 
Atestatsijna Komissiya (DAK)] that conducts accreditation withdrew licenses of 116 educational programs, branches, affiliates, and colleges only in 2006.

Licenses were recalled, among others, from the Kiev business-college, educational programs of Kharkov National University of the Ministry of the Interior in Smila, Poltava, Melitopol, Yevpatoriya, Kerch, Mariupol, Herson, the educational branch of Kharkov Aeronautical University in Alushta, and a branch of the East-Ukrainian University in Feodosiya. The Autonomous Republic of Crimea appears to be a very attractive place for branches and programs of HEIs, some of which are below the standards, set by the Ministry of Education and Science.

\section{OPINIONS ON CORRUPTION IN EDUCATION}

The country's prominent politicians, educators, and the media pay more attention to the problem of corruption in education now than they did before. The President of Ukraine, Victor Yushchenko has asked state universities to curtail the corruption so endemic to admissions processes and called upon rectors and professors to put a stop to the bribery and cronyism that hold sway during entrance exams, a widespread practice that he characterized as "shameful and humiliating.” (MacWilliams, 2005, p. A33) He pointed out corruption in education in his address to the students of Kiev National University in March 9, 2007 (Vystup, 2006). On June 12, 2007, the Hall of the Academy of Sciences of Ukraine in Kiev hosted a conference entitled "The Major Corruption Schemes in the Education System and the Ways to Eradicate Them.” (Osvita, 2007a) These two events, the Presidential address and the Conference, are illustrative of the scale of the problem of corruption in higher education and of the level of attention it receives from the country's leadership, the public, and the media.

The authorities acknowledge the presence of corruption in education (Bazhal et al., 2006). However, the official position of all of the rectors is that there is no corruption in their HEIs and that the highest consideration is given to knowledge of the applicant. It is assumed that admission to leading HEIs will not be granted to an applicant whose academic knowledge is not strong enough, even if he is ready to pay the tuition (Shamrai, 2007).

The fate of the standardized test as a part of the recent educational reform is of high concern as well. The independent external testing intended to replace outdated oral entry examinations is considered as an effective tool in fighting corruption in admissions to publicly funded HEIs (Shamrai, 2007). The test is designed to provide independent estimates of the high school graduates' knowledge and the test score should be the major or the only criterion in admissions decisions in colleges and universities. However, many believe that 
the standardized test will not solve the problem of academic corruption not only in the educational process, but even in admissions. An Academician of the National Academy of Sciences of Ukraine, Volodymyr Semynozhenko says that "Corruption in our country is not a narrow phenomenon confined to a particular branch or an industry. This is a countrywide problem. Hence, the fight against corruption should start with the independent testing of state bureaucrats and politicians.” (Osvita, 2006) This opinion places the issue of corruption in academia in a broader context, pointing to widespread corruption in many areas of economic and social life of the society and of a corrupt political structure.

The real intent of the external or independent testing may be in selecting students with certain characteristics needed for each specialty, and not granting admissions based simply on the higher scores obtained by the test-takers. Fully equipped test centers, computerized networks, and specialists are also needed (Adzhimuratova, 2006). The situation reveals a number of potential problems, including miscommunications between the Ministries, unclear regulations and structural frameworks for implementing the reform.

The majority of rectors are against the test. Clear sabotage is anticipated in the future on the side of some of the rectors in order to compromise the test. The Minister of Education agrees that the tests will not replace the entry examinations completely. Some oral examinations will be preserved. This $a$ priori leaves some space for corruption in college admissions.

\section{ESTIMATES OF CORRUPTION IN EDUCATION}

Numerous accusations of corruption as related to higher education, including admissions and academic process, and, more recently, the standardized test, necessitate presenting some estimates about corruption's scale and scope in the nation's education industry. The survey conducted by the Institute of Social and Political Psychology of the Academy of Pedagogical Sciences in 2006 targeted students in the leading educational centers of the country, including Kiev, Kharkov, Donetsk, Lviv, and Odessa. The following responses were obtained to the question "How in your opinion has the situation with corruption in entering higher education institutions changed compared to the previous years?": around 20 percent of the respondents indicate that they know of the cases of bribery, but the number of such cases has declined; around 27 percent of students said that bribes were accepted by the faculty members at about the same level, as they were in previous years and that nothing has changed; 7 to 8 percent think that bribery is now flourishing. The number of students who admitted paying bribes for entering the college or university declined from 19 percent in 2005 to 13 percent in 2006 (Bazhal et al., 2006). 
Relatives, friends, and bribe-givers occupy the majority if not all of the publicly funded places in HEIs. All trends point toward increasing sums of bribes paid and development of more sophisticated schemes of bribery. The higher the tuition in the for-tuition program, the higher the "price" of admission to a statefunded place in the same school becomes. The size of every bribe varies depending upon parents' wealth, degree of connections with the person, who arranges the admission, etc. In some of the most elite HEIs even a bribe will not help to gain admission. In these universities places are thought to be distributed among the children of politicians, businessmen, and top bureaucrats (Grishina and Korchinsky, 2006). An attempt to estimate the total potential volume of corruption in Ukraine's higher education has yet to be made. Neither surveys nor mass media reports set any estimates of the overall corruption in higher education but rather present a mosaic of cases and speculations.

\section{MEASURES TO RESIST CORRUPTION IN HIGHER EDUCATION}

The high cost of education and growing demand on higher education from the population, along with the low salaries of the faculty and staff create a fertile ground for corruption. An increase in public perceptions of corruption in higher education facilitates a further increase in corruption as well as in the total amount of corrupt benefits accumulated by the faculty and staff. Newly designed and gradually implemented rules and mechanisms of admissions policies and administering entry examinations may not be working well.

Perceptions about the high level of corruption in bureaucracies and in the public sector in general, shared by the population, are found to increase actual corruption (Cabelkova and Hanousek, 2004, Olken, 2006). In the corrupt environment of higher education in Ukraine, where the level of prosecution is low and the risk of being prosecuted is low as well, one of the major problems that corruptors in academia face is an informational vacuum. The problem of asymmetric information, well described in economic literature, is a big issue in corrupt agreements and negotiations.

Education corruption has a leading role in creating a culture of corruption in the society, where one has to make informal payments and gifts in kindergarten, school, and college. Corruption in academia is acknowledged and broadly discussed by the media and the public. Such a discussion urges public officials, responsible for the situation in education, to voice concerns and to present a set of measures that would adequately respond to growing corruption in the education industry.

A set of anti-corruption measures includes organizational, economic, and legal means (Bazhal et al., 2006). Organizational measures include better and 
clearer admissions processes as well as the newly established office within the Ministry of Education and Science that follows the cases of corruption in education throughout the country. The Ministry also has its representative in each of the country's regions, who, along with the civic committee, responds to the cases of corruption. The authorities also rely on the emerging civil society, switching the focus from the investigation of specific cases of corruption to enhancing legal literacy through educational work among the population and increasing people's awareness of the issue. Students are also more involved in fighting corruption. They are no longer a mere object of educational process but its participants. The student council works closely with the Ministry. This allows for a better informational flow from HEIs to the Ministry of Education and Science.

Among the economic measures the key focus is on the instructors' salaries. The Minister of Education points out that just 2-3 years ago the instructor's monthly salary was equal to $400 \mathrm{UAH}$ or $\$ 80$. He says that “In order to buy an apartment a professor would have to work for 126 years without eating and drinking. This created economic ground for corruption that still exists now... During the last two-and-a-half years the salaries almost doubled. A college instructor now earns around 1370UAH or \$274. This process will continue and economic ground for corruption will disappear.” (Bazhal, 2006)

The legal measures include an increasing vigilance and awareness among the law enforcement agencies, rectors, and the public that resulted in around 400 cases of bribery being disclosed, investigated, and prosecuted. The active role of students and collective action will make involvement in corrupt activities less attractive and more risky. The Leader of the Peoples-Democratic League of Youth calls for a law that would delegate more authority to the student union (Osvita, 2007b).

The Minister of Education emphasizes such technical measures in fighting corruption, as working closely with rectors and faculty, meeting regularly with student leaders, conducting anonymous surveys, and undertaking numerous controlling measures and investigations. At the same time he accuses students and their parents in perpetuating corruption by presenting excessive demands for higher grades and admissions, supported by bribes.

The Ministry of Education and Science regularly reminds college faculty and administrators that they do not have a right to collect fees and fines for retaking the test or missing classes, as well as the necessity to conduct examination sessions in a set period. The Ministry also maintains a hot line during examination sessions, so everyone can call and report suspicious activities that may take place in HEIs. The Head of the Department of Higher Education in 
the Ministry says that "The ministry does everything to make bribery and protectionism in higher education impossible.” (Bolyubash, 2006; Shamrai, 2007) He also points to an introduction of "hot lines", when anyone can call to the Ministry and report law violations. This, however, may lead to the opposite reaction. In one of the HEIs the Student Council posted numerous information posts with the hot line phone number to report possible cases of corruption. As a result, students took down these posters and called to complain that faculty members now are afraid of taking bribes and so it is more difficult to pass the examination session (Shadnaya, 2006). Also, the Education Ministry's "hot lines," for some reason, are only open during the admissions sessions.

Sophistication of corrupt schemes increases along with the development of different techniques aimed at reducing corruption. Fraud becomes commonplace in the educational industry and even within the corrupt activities. For instance, the law requires all the HEIs to provide complete, reliable, and truthful information about the educational programs offered, as well as license number and level of accreditation. In practice, however, some HEIs provide incorrect or incomplete information, fail to maintain the state license or pass the state accreditation. Trust as a necessary prerequisite of transactions in the marketplace is abused not only in the market of educational services, but within the corrupt transactions as well. Grishina and Korchinsky (2006) identify one of the techniques used by the corrupt educators as a promise of helping an applicant to gain admission to a state-funded program in exchange for a bribe. The faculty member who might not be even on the admissions committee or in a position to influence admissions decisions takes money and then simply waits to see if the applicant will pass the entry examinations. If the applicant is successful, the money stays with the faculty member.

Every institution and educational leader may be found lobbying certain interests. In Seminozhenko's view “The school tests can simply lead to the redistribution of corruption flows in education and nothing else. Under the current circumstance in the country, where an objective law of perpetuation of corruption works, loopholes will be found any way. Moreover, the level of knowledge children receive in schools, for which the Ministry of Education and Science is responsible, is tested by the Center for Educational Quality Evaluation, which also reports to the Ministry. The first step toward the honest education evaluation should become creation of a truly independent testing institution." (Osvita, 2006)

Demographic problems create pressure on corrupt practices as well. Some of the schools and numerous kindergartens are being closed for there are not enough children to educate. In 2006 there were 97 schools closed out of 20 
thousand (Smolyana and Katrichenko, 2006). At the same time the number of applicants per one state-funded place in such majors as economics, banking, and finance in the elite HEIs is around 10 people per place and higher. Computer sciences draw 5 to 7 applicants per place, and even humanities, including cultural anthropology, history, philosophy, and political science, enjoy large numbers of applicants (Ksenz, 2006).

\section{CONCLUSION}

Ukraine presents all of the forms of corruption in higher education that may be found throughout the world. The wide spectrum and rich colors of the problem make the higher education sector in the country of high interest to the researchers. Ukrainian education is undergoing a major transformation, part of which is focused on curbing corruption in the academia. The high reputation and status of Ukrainian educational credentials have to be restored, but the process has to take place in rapidly changing conditions.

There are a few major changes coming in higher education, including an introduction and nationwide implementation of the standardized test and the adjustment of the admissions policies. When the test partially replaces the entry examinations in colleges and universities, corruption will extend to secondary education and testing centers, indicating a spillover effect.

The continuous privatization of higher education services will likely leave less corruption in state-university relations, including embezzlement, fraud, gross waste, and misallocation of resources, typical for a centralized state-funded system. At the same time corruption in customer-provider relations may increase. Provision of false information and fraud may grow. Further decentralization of the nation's higher education system, along with growing privatization and an expected increase in the cost of education will lead to an increase in the total volume of the market of educational loans. This will broaden the base for possible corruption in the financial sphere that will regulate the availability of educational loans and the characteristics of private banks as providers of such loans.

The declining monopoly of the Ministry of Education and the emerging multi-centricity in higher education will facilitate increasing the role of nongovernmental organizations, civil society institutions, student unions, and consortiums of public and private HEIs. Further market reforms may be needed to build the international reputation of Ukrainian universities and educate consumers of educational services. The issue of mutual responsibility and collective reputation becomes an integral part of the concept of intellectual integrity, when every academic carries a responsibility over the standards of 
education and conduct in the academic community. Modernization of modes of delivery, curriculum, and instruction, introduction of standardized testing, and development of university autonomy will help curb corruption in higher education. 


\section{References}

Adzhimuratova, Y. (2006). Esli v nazvanii uchebnogo uchrezhdenija est' slovo "mezhdunarodny," "planetarny” ili drugie podobnye slovesa, to eto - vsego lish "mylny puzyr" [If there is "international," "planetary," or similar terms in the name of the HEI, then this is just a "bubble”]. Osvita, May 4, 2006. Retrieved June 12, 2007, from http://www.osvita.org.ua/articles/64.html

Anechiarico, F., \& Jacobs, J. (1995). The Pursuit of Absolute Integrity: How Corruption Control Makes Government Ineffective. Chicago, IL: University of Chicago Press.

Bazhal, A., Galkovska, T., Skripnik, O., \& Surzhik, L. (2006). Znannya optom i vrozdrib, abo Nezruchni zapytannja do ministra osvity i nauky [Knowledge for sale, or Inconvenient questions to the Minister of Education and Science]. Dilovyj Tyzhden, June 5, 2006. Retrieved June 12, 2007, from http://www.osvita.org.ua/articles/218.html

Bolyubash, Y. (2006). Dopovidna zapiska pro stan roboti shodo vikorinennja, profilaktiki i zapobigannju projaviv habarnictva ta inshih negativnih javish u sferi osviti [The report about the efforts of eradicating and preventing bribery and other corrupt phenomena in the education sector]. The Ministry of Science and Education of Ukraine, December 18, 2006. Retrieved March 24, 2007, from http://www.mon.gov.ua/education/higher/rozv/2006/18_12_2.doc

Cabelkova, I., \& Hanousek, J. (2004). The Power of Negative Thinking: Corruption, Perception and Willingness to Bribe in Ukraine. Applied Economics, 36(4), 383.

CityNews, December 25, 2006. Byvshy rector luganskogo filiala MAUP prisvoila 831,9 tysyach griven [Former rector of the Lugansk branch of MAUP embezzled 831.9 thousand UAH]. Retrieved March 24, 2007, from http://www.citynews.net.ua/5/8925_1.html

Gazeta. (2006). Stanislav Nikolaenko: "Ya - ministr s 'borodoy”” [Stanislav Nikolaenko: “I am a Minister with the 'beard'”]. Gazeta po-kievski, December 12, 2006. Retrieved June 12, 2007, from http://www.osvita.org.ua/articles/166.html

Grishina, K,. \& Korchinsky, V. (2006). Kak postupit v VUZ, ne davaya na "lapu”? [How to enter a HEI without paying a bribe]. Segodnya, July 17, 2006. Retrieved June 12, 2007, from http://www.osvita.org.ua/articles/123.html

Hallak, J., \& Poisson, M. (2007). Corrupt Schools, Corrupt Universities: What Can Be Done? Paris: Institute for International Educational Planning.

Heyneman, S., Anderson, K., \& Nuraliyeva, N. (2008). The Cost of Corruption in Higher Education. Comparative Education Review, 52(1), 1-26.

Heyneman, S. (2007). Three Universities in Georgia, Kazakhstan and Kyrgyzstan: the struggle against corruption and for social cohesion. Prospects: Quarterly Review of Comparative Education, 37(3), 305-318

Heyneman, S. (2004). Education and Corruption. International Journal of Educational Development, $24,638$.

Janashia, N. (2004). Corruption and Higher Education in Georgia. International Higher Education, 34(Winter 2004) $10-12$.

Johnston, M. (1996). The Search for Definitions: The Vitality of Politics and the Issue of Corruption. International Social Science Journal, 149, 322.

Kerr, C. (1993). Universal Issues in the Development of Higher Education. In Balderston, J.B. and Balderston, F. (Eds.). Higher Education in Indonesia: Evolution and Reform. Berkeley: Center for Studies in Higher Education, University of California, pp. 19-35.

Km.ru. Darenye koni ot bednyh studentov [Gifts from poor students]. Km.ru, February 4, 2007. Retrieved June 12, 2007, from http://www.osvita.org.ua/articles/188.html

Ksenz, L. (2006). Zolotoj diplom. Stoimost' obucheniya v stolichnyh vuzah b'et vse rekordy [Golden diploma. The cost of education in the capitol's HEIs goes record high]. Delovaya stolitsa, June 19, 2006. Retrieved June 12, 2007, from http://www.osvita.org.ua/articles/77.html

MacWilliams, B. (2005). Ukraine's president asks universities to end corruption in admissions process. The Chronicle of Higher Education, 51(43), A20.

Miller, S., Roberts, P., \& Spence, E. (2005). Corruption and Anti-Corruption: An Applied Philosophical Approach. Upper Saddle River, NJ: Prentice Hall.

Milovanovic, M. (2001). Endogenous Corruption in Emerging Industrial Relations. Budapest: The Hungarian Academy of Sciences. Retrieved May 12, 2002, from www.policy.hu/milovanovic/corruption.html 
Ministerstvo Pratsi ta Sotsial'noji Polityki Ukrajiny [Ministry of Labour and Social Policy of Ukraine]. Retrieved August 6, 2008, from http://www.mlsp.gov.ua/control/uk/archive/doctypes

Olken, B. (2006). Corruption Perceptions vs. Corruption Reality. Paper presented at the annual conference of the NEUDC, Cornell University, Ithaca, NY, November 2006.

Osborne, D. (1997). Corruption as Counter-Culture: Attitudes to Bribery in Local and Global Society. In B. Rider (Ed.). Corruption: The Enemy Within. Dordrecht: Kluwer.

Osipian, A. (2010). Dissertations for Sale: Corruption in Russia's Doctoral Education. Annual Meeting of the American Economic Association, Atlanta, GA, January 2010.

Osipian, A. (2009a). "Feed from the Service": Corruption and Coercion in the State-University Relations in Central Eurasia. Research in Comparative and International Education, 4(2), 182-203.

Osipian, A. (2009b). Vouchers, Tests, Loans, Privatization: Will They Help Tackle Corruption in Russian Higher Education? Prospects: Quarterly Review of Comparative Education, forthcoming.

Osipian, A. (2009c). Investigating Corruption in American Higher Education: The Methodology. FedUni Journal of Higher Education, 4(2), 49-81.

Osipian, A. (2009d). Corruption Hierarchies in Higher Education in the Former Soviet Bloc. International Journal of Educational Development, 29(3), 321-330.

Osipian, A. (2009e). Corruption in the Higher Education Industry: Legal Cases in the Context of Change. Annual Conference of the University Council for Education Administration, Anaheim, CA, November 2009.

Osipian, A. (2009f). Le Bourgeois Gentilhomme: Political Corruption of Russian Doctorates. Annual Meeting of the American Sociological Association, San Francisco, CA, August 2009.

Osipian, A. (2009g). Grey Areas in the Higher Education Sector Finance: Illegality versus Corruption. Annual Meeting of the American Education Finance Association, Nashville, TN, March, 2009.

Osipian, A. (2009h). Corrupt Organizational Hierarchies in the Former Soviet Bloc. Transition Studies Review, 16(3), forthcoming.

Osipian, A. (2008a). Corruption and Coercion: University Autonomy versus State Control. European Education: Journal of Issues and Studies, 40(3), 27-48.

Osipian, A. (2008b). Modeling Educators' Misconduct with Cellular Automata. Annual Conference of the American Sociological Association (ASA), Boston, MA, August 2008.

Osipian, A. (2008c). Political Graft and Education Corruption in Ukraine: Compliance, Collusion, and Control. Demokratizatsiya: The Journal of Post-Soviet Democratization, 16(4), 323-344.

Osipian, A. (2008d). Corruption in Higher Education: Does it Differ Across the Nations and Why? Research in Comparative and International Education, 3(4), 345-365.

Osipian, A. (2008e). Book Review of Corrupt Schools, Corrupt Universities: What Can Be Done? Paris: Institute for International Educational Planning by Jacques Hallak and Muriel Poisson. Canadian and International Education Journal, 37(2), 99-101.

Osipian, A. (2007a). Corruption in Higher Education: Conceptual Approaches and Measurement Techniques. Research in Comparative and International Education, 4(2), 313-332.

Osipian, A. (2007b). Higher Education Corruption in Ukraine: Opinions and Estimates. International Higher Education, 49, 12-15.

Osipian, A. (2007c). Corruption Hierarchies in Education in Developing and Transition Societies. Proceedings of the Annual Conference of the University Council for Education Administration (UCEA), Alexandria, VA, November. Available at http://coe.ksu.edu/ucea

Osipian, A. (2007d). Replacing University Entry Examinations with Standardized Tests in Russia: Will It Reduce Corruption? Proceedings of the Annual Conference of the University Council for Education Administration (UCEA), Alexandria, VA, November 2007. Available at http://coe.ksu.edu/ucea

Osipian, A. (2007e). Higher Education Corruption in the World Media: Prevalence, Patterns, and Forms. Annual Conference of the Association for the Study of Higher Education (ASHE), Louisville, KY, November 2007.

Osipian, A. (2007f). "Feed from the Service": Corruption and Coercion in the State-University Relations. Annual Conference of the Central Eurasian Studies Society (CESS, Harvard), University of Washington, Seattle, WA, October 2007.

Osipian, A. (2007g). Corruption and Reform of Russian Higher Education. Annual Meeting of the American Sociological Association (ASA), NYC, August 2007. 
Osipian, A. (2007h). Graft in Academia: International Perspectives on Corruption in Higher Education. Beyond Borders: Global Change and Education in Action. New York University, NYC, March 2007.

Osipian, A. (2007i). Corruption in Secondary and Higher Education: Conceptual Approaches and Investigative Techniques. Annual Conference of the Comparative and International Education Society (CIES), University of Maryland, Baltimore, MD, February 2007.

Osipian, A. (2007j). Higher Education Corruption in Ukraine as Reflected in the Nation's Media. The Education Resources Information Center (ERIC). Available at http://www.eric.ed.gov/

Osipian, A. (2006). Corruption in Higher Education in Organizational Perspective: Case of the Former Soviet Bloc. $50^{\text {th }}$ Annual Conference of the Comparative and International Education Society (CIES) "Rethinking the Comparative," University of Hawaii, Honolulu, HI, March 2006.

Osipian, A. (2005). Corruption of the Politicized University: Lessons from the Orange Revolution in Ukraine. $100^{\text {th }}$ Annual Conference of the American Sociological Association (ASA), Philadelphia, PA, August 2005.

Osipian, A. (2004a). Corruption as a Legacy of the Medieval University. Annual Conference of the Association for the Study of Higher Education (ASHE), Kansas City, November 2004.

Osipian, A. (2004b). Legacies of Medieval Universities of Bologna and Paris: What to Preserve and What to Leave Behind. International Scientific-Practical Conference "Perspectives of Development of the Social Sciences and Humanities in Classical Universities (sociology, psychology, pedagogy).” Taras Shevchenko Kiev National University, Kiev, Ukraine, May 2004.

Osvita. (2006). Akademik NANU Volodymyr Seminozhenko: nezalezhne testuvannya vypusknikiv ne vyrishyt problemu koruptsii [The Academician of NANU Volodymyr Seminozhenko: the independent testing of high school graduates will not solve the problem of corruption]. Osvita, June 23, 2006. Retrieved June 12, 2007, from http://www.osvita.org.ua/news/?news_id=21269

Osvita. (2007a). U Kyevi vidbulasya konferentsiya "Osnovni koruptsijni shemi v sistemi osviti ta shlyahi ïh podolannya" [Kiev hosted a conference entitled "The Major Corruption Schemes in the Education System and the Ways to Eradicate Them]. Osvita, June 13, 2007. Retrieved June 13, 2007, from http://www.osvita.org.ua/news/28874.html

Osvita. (2007b). V Ternopoli zatrymaly vykladachku, yaka vstanovyla "taryfy" na ocinky v vuzi [There was an instructor detained in Ternopol, because she set a pricelist for grades in the HEI]. Osvita, June 13, 2007. Retrieved June 13, 2007, from http://www.newsru.ua/crime/13jun2007/wr.html

Petrov, G., \& Temple, P. (2004). Corruption in Higher Education: Some Findings from the States of the Former Soviet Union. Higher Education Management and Policy, 16(1), 82-94.

Reeves, M. (2004). Academic Integrity and Its Limits in Kyrgyzstan. International Higher Education, 34, 2224.

Sanghera, B., \& Romanchuk, N. (2002). Bribery in Kyrgyz State Universities. Is there anything to worry about? Research paper, 2002. Retrieved April 5, 2007, from http://uk.geocities.com/balihar_sanghera/qrmnadezhdaromanchukbriberyinuniversities.html

Satarov, G. (2006). Corruption Process in Russia: Level, Structure, Trends. In G. Satarov (Ed.). Diagnostics of Corruption in Russia: 2001-2005. INDEM Foundation. Retrieved May 12, 2006, from http://www.indem.ru/en/publicat/2005diag_engV.htm

Sayed, T., \& Bruce, D. (1998). Police Corruption: Towards a Working Definition. African Security Review, 7(1). Retrieved May 20, 2002, from http://www.iss.co.za/ASR/7No1/SayedBruce.html

Shadnaya, O. (2006). Vzyatka: mif, o kotorom vse slyshali, no nikto ne videl? [A bribe: is it a myth of which everyone heard but no one seen?]. Context, February 2, 2006. Retrieved June 12, 2007, from http://www.osvita.org.ua/articles/50.html

Shamrai, N. (2007). V VUZ ljuboj tsenoj [Into HEI at any cost]. Glavred, June 6, 2007. Retrieved June 12, 2007, from http://www.glavred.info/archive/2007/06/06/123144-6.html

Shaw, P. (2005). The Determinants of Educational Corruption in Higher Education: The Case of Ukraine. Paper presented at the 2005 NEUDC Conference, Yale University, New Haven, CT.

Silova, I. (2005). Traveling Policies: hijacked in Central Asia. European Educational Research Journal, 4(1), 50-59.

Silova, I., \& Bray, M. (2006). The Hidden Marketplace: Private Tutoring in Former Socialist Countries. In I. Silova, V. Budijene, and M. Bray (Eds.), Education in a Hidden Marketplace: Monitoring of Private Tutoring. Budapest: Open Society Institute. pp. 71-98. 
Silova, I., Johnson, M., \& Heyneman, S. (2007). Education and the Crisis of Social Cohesion in Azerbaijan and Central Asia. Comparative Education Review, 51(2), 159-180.

Smolyana, I., \& Katrichenko, T. (2006). Ministr Stanislav Nikolaenko: "V odnom iz sel Rovenskoj oblasti v shkolu pojdet tol'ko odin uchenik... Eto normal'no?” [Minister Stanislav Nikolaenko: “There is only one pupil went to one of the schools in Rovno region... Is this normal?”]. Glavred, August 31, 2006. Retrieved June 16, 2007, from http://www.glavred.info/archive/2006/08/31/122418-8.html

Stetar, J., Panych, O., \& Cheng, B. (2005). Confronting Corruption: Ukrainian Private Higher Education International Higher Education, 38, 13-15.

Tarling, N. (2005). Corruption and good governance in Asia. New York : Routledge.

Temple, P. (2006). Universities without Corruption: A New Approach for Georgia's Higher Education. International Higher Education, 42, 19-20.

Unian. (2007). Rozpochavsya sezon habariv v vuzah [The season of bribery in HEIs has began]. Unian, June 13, 2007. Retrieved June 13, 2007, from http://www.unian.net/ukr/news/news-199511.html

Vystup Prezydenta Ukrainy pered studentamy Natsionalnogo universitetu im. Tarasa Shevchenka (9 bereznya 2006) [The President of Ukraine addresses students of Taras Shevchenko Kiev National University (March 9, 2006)]. Pres-sluzhba Prezydenta Ukrainy, March 27, 2006. Retrieved June 12, 2007, from http://www.osvita.org.ua/articles/59.html

Waite, D., \& Allen, D. (2003). Corruption and Abuse of Power in Educational Administration. The Urban Review, 35(4), 281-296.

Yang, R. (2005). Corruption in China's Higher Education System: A Malignant Tumor. International Higher Education, 39, 18-20.

Ararat L. Osipian is a PhD candidate in the Department of Leadership, Policy, and Organizations at Peabody College of Education at Vanderbilt University. He can be reached at Ararat.osipian@vanderbilt.edu 